US-Canada dispute

\section{Acid rain settlement in sight?}

Washington

THE seven-month deadlock between the United States and Canada over acid rain pollution may be breaking. Secretary of State George P. Shultz discussed the issue with Canadian foreign minister Allan MacEachen on 25 October; summary papers are now being exchanged between them. And representatives of both sides, whose last meeting ended stormily in June, plan to resume discussions in February.

One US official said he was "cautiously optimistic" that the deadlock could be broken "now that the two sides' foreign ministers have involved themselves personally" in the issue. The Canadian government, for its part, has modified the somewhat belligerent tone of its statements on the US position.

After taking office in 1981, the Reagan Administration rejected a Canadian call to reduce US sulphur dioxide emissions by 50 per cent a year, which, according to OTA, would cost as much as $\$ 2,700$ million per year and raise electricity rates for US consumers in the Eastern United States.

When, last fall, the National Academy of Sciences study essentially confirmed the Canadian view that the evidence of cause and effect was "overwhelming", the White House Office of Science and Technology Policy declared that the academy was not sufficiently unbiased to serve as a review group to the technical work of the joint working groups. It gave the job of peer review to a special group under the Office of Science and Technology Policy and headed by William Nirenberg, director of the Scripps Institution of Oceanography.

But within the US coordinating committee, as the US representatives are called, and within the US delegations to the joint working groups, there has been strong disagreement on how to interpret the evidence on acid rain. One scientist said that under the Carter Administration, the groups were encouraged to be liberal in their interpretation of the data. The new group, especially officials from the Environmental Protection Agency and the Department of Energy, are "much more conservative" in the way they extrapolate impacts from the limited data.

Acid rain has therefore become one of the Reagan Administration's most troubling science policy issues. It entails many scientific uncertainties (see accompanying story). It could cost $\$ 2,000-2,700$ million per year to reduce sulphur dioxide emissions of US utilities by half, to 8 million tons per year, if controls are implemented, according to Congress's Office of Technology Assessment (OTA). On the other hand, if controls are not implemented and it turns out that acid rain is the culprit in much environmental damage the US fishing, forestry and agricultural industries could be hurt.

The US Administration, accused by Canada of ruining its lakes and fish, must decide when enough is known about the problem to justify a public policy decision. Says one congressional staff member who has studied the risks and benefits of controlling acid rain: "I would hate to have to decide this. That's what we elect politicians for."

Elected officials in Congress may take the initiative away from the Reagan Administration in coming months, when they take up the need to revise the Clean Air Act. The act is intended to control local air pollution and does not address the longrange transport of pollutants from high stacks across state and international boundaries. In the previous Congress, several New England congressmen sponsored amendments to the Clean Air Act that would have required clean-up by power plants - a burden that would fall most heavily on states in the midwest. But the revisions to the act were not passed.

The politics of acid rain may be different in the new Congress, however. A new study by James $\mathbf{M}$. Omernik and Charles $\mathbf{F}$. Powers of EPA's Corvallis laboratory suggests that surface waters in southern states, such as Louisiana, Mississippi and Alabama, may be affected adversely by acid rain as well. So powerful midwestern Senators, such as Richard G. Lugar (Republican, Indiana) may have to fight a broader group favouring controls.

On 5 January, the State Department told Canada why the Administration feels that the scientific uncertainties are too great to warrant regulatory action now in the United States. The department is expecting a paper from the Canadian government explaining that country's position that enough is known to warrant interim and long-term measures. The papers are expected to be the basis for further talks between Shultz and MacEachen.

When it took office, the Reagan Administration reversed the Carter Administration's position that some kind of joint USCanadian action might be necessary soon, and that joint studies should be made as quickly as possible to determine what that action should be.

In a joint statement in July 1979, the Carter Administration and the Canadian government agreed that some kind of environmental agreement should be sought on acid rain. In a memorandum of intent signed in August 1980, the two governments agreed to work towards such an agreement, to discuss interim measures, and to set up joint working groups to figure out the issues.

\title{
Three points of contention
}

THE Reagan Administration's position is that scientific uncertainty over three major issues makes any new restrictions on power-plant emissions unjustified:

- Transformation of sulphur dioxide $\left(\mathrm{SO}_{2}\right)$ and nitrogen oxides $\left(\mathrm{NO}_{\mathrm{x}}\right)$ to acids. The complete chemical pathway of these transformations in the atmosphere has yet to be worked out, and variations in the acidity of rain over time and space are not well explained by current theory. Some evidence suggests that the limiting factor in the oxidation of $\mathrm{SO}_{2}$ and $\mathrm{NO}_{x}$ to sulphuric and nitric acids may be the availability of atmospheric oxidants, such as ozone and peroxide. "Conceivably", said Courtney Riordan, assistant administrator for research at the Environmental Protection Agency (EPA), "you could have a significant reduction in emissions and see no improvement in deposition as a result"'. - Transport and distribution of $\mathrm{SO}_{2}$ and $\mathrm{NO}_{\mathrm{x}}$ in the atmosphere. Not enough is known about either long-range or local transport of acid-rain precursors to refine models to the point where a specific powerplant's emissions may be linked to acid rain at a specific downwind site.

- Natural acidity of rain. "There is no good measure of when acidity in rain should be considered detrimental", said EPA assistant administrator Kathleen Bennett. Unpolluted rain may have a $\mathrm{pH}$ above or below $\mathrm{pH} 5.6$, the theoretical natural level based on equilibrium with atmospheric $\mathrm{CO}_{2}$.

The Administration has put itself at odds not only with Canada but also with its own National Academy of Sciences in taking this line. "Although claims have been made that direct evidence linking powerplant emissions to the production of acid rain is inconclusive", an academy panel said in 1981, "we find the circumstantial evidence for their role overwhelming"'.

And both the academy and the Canadian government maintain that the goal of being able to link specific sources with specific environmental damage is impossible. George Rejhon of the Canadian Embassy in Washington said, "When you start working towards 'scientific certainty' you can go on forever. There are certainly some people in EPA who seem to be demanding such a degree of scientific precision that they want the natural world to be like a man-made laboratory. That is not possible."

Rejhon said the Canadian view is that enough is already known to take action on limiting $\mathrm{SO}_{2}$ emission from power plants. He said that although it may not be possible to say how much a given region will benefit from a given reduction in emissions, the evidence is that at least 90 per cent of the acidity in areas of concern is man-made. Thus reductions in overall atmospheric loading of $\mathrm{SO}_{2}$ will produce overall benefits in the affected areas.

Stephen Budiansky 